\title{
Contextualisation: A case study of a team within an international missional order
}

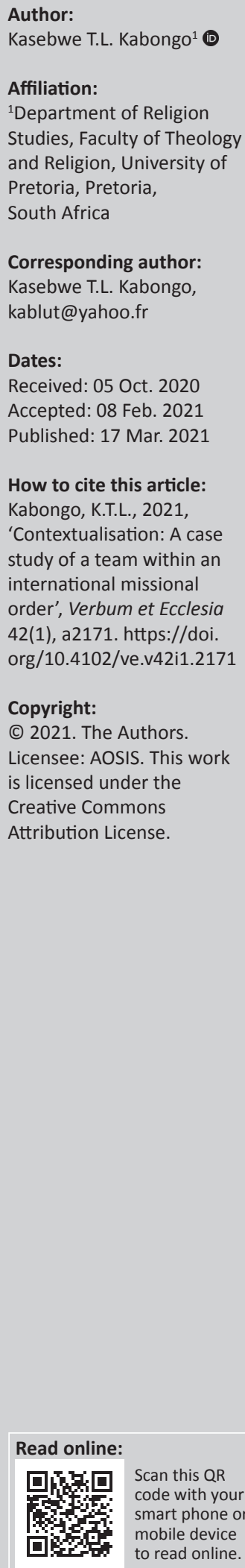

Contextualisation is a process of seeking meaning and relevancy in a constantly changing world. It is a theological imperative if biblical values were to be relevant to everyone in the world. This research is a case study of InnerCHANGE South Africa (ICSA) efforts to be contextual. InnerCHANGE South Africa is part of an international missional order called InnerCHANGE, which was started in 1984 in the United States of America. International organisations face the danger of coming up with uniform principles and practices. Such uniformity is never innocent of cultural bias. It rendered their principles and practices relevant in some contexts and irrelevant in others. InnerCHANGE is an incarnational ministry that focuses on identification in communities of poverty. It described incarnational ministry as a model of Christ, a method, a message and a spiritual discipline. This study investigated how ICSA has been able to contextualise these four elements of incarnational ministry. It concluded that these contextualisation efforts are still work in progress. It pointed out the encouraging signs of seeing many local community members aligning themselves behind ICSA vision of seeing the gospel as the good news made visible. It finally pointed out the challenges of contextualisation it is still facing.

Intradisciplinary and/or interdisciplinary implications: This article is based on the field of missiology. It engaged development studies, specifically grassroots community development, to point out one of the roles of the church in society, which is to participate in improving the quality of life of the vulnerable.

Keywords: context; good news; identification; incarnation; relevance.

\section{Introduction}

Contextualisation is a process of seeking meaning and relevancy in a constantly changing world. In mission work, it can be described as the 'process where the gospel is assimilated into the total life of the people in their cultural context so that the message makes sense' (Bangura 2016:2). This process is 'a theological imperative' and must remain consistent with biblical values (Bevans \& Schroeder 2004:384). This research is a case study about InnerCHANGE South Africa (ICSA thereafter) efforts to be contextual. InnerCHANGE South Africa is part of an international missional order called InnerCHANGE. The latter currently has 16 teams in five continents around the world. InnerCHANGE was founded by John Hayes in 1984 in the United States of America. Its members follow 'common rhythms, commitments and values' (innerchange.org 2020). They live in communities of poverty 'motivated by the love and gratitude that comes from walking with God' (innerchange.org 2020). In those communities, they focus 'on discipleship, the development of local leaders who are marked by merciful action, transformative contemplation and prophetic justice' (innerchange.org 2020). They pursue agency from below in catalysing community transformation inspired by the biblical passage 'to do justice, love mercy and walk humbly with our God' (Mi 6:8). They pursue incarnational ministry. Incarnational for them refers 'to a mission that envisions becoming like the people [they] are praying to reach' (Hayes 2006:16). It is about identification with the poor and a search to emulate biblical values in a way that is understandable, meaningful and tangible. Hayes (2006:114-120) describes incarnational ministry as 'a model of Christ, a method, a message and a spiritual discipline'. InnerCHANGE uses these four elements to implement its ministry approach. These four elements have been the focus of ICSA efforts of contextualisation, which this article discusses. InnerCHANGE South Africais located in the township ${ }^{1}$ of Soshanguve and serves in its surrounding townships.

1.Townships are poor urban locations which were initially set up for non-white migrant workers. They are located outside of urban centres. The majority of its residents are still poor and at the receiving end of many systemic injustices and trauma. 
International organisations such as InnerCHANGE face the danger of coming up with uniform principles and practices. Such uniformity is never innocent of cultural bias. It renders their principles and practices relevant in some contexts and irrelevant in others. This research investigates how ICSA has attempted to contextualise the above-mentioned four elements describing incarnational ministry. InnerCHANGE South Africa believes that for it to remain relevant to the people it is called to, 'it must address issues' that are meaningful to them (Beyers 2016:6). In its efforts to be contextual, ICSA has been asking: what does it mean to be a relevant missional order amongst its neighbours? It is answering this question by engaging the above-mentioned four elements of incarnational ministry.

\section{The four elements of incarnational ministry Model of Christ}

The supreme statement of the incarnation is found in the gospel of John (1:14). This passage declares that 'the Word became flesh and made his dwelling among us'. InnerCHANGE interprets this passage as a call to intentionally be part of the fabric and tissues of local communities it serves. The goal is to identify with the people it is called to serve so that its staff can become neighbours who trust each other and partner to improve the quality of life around them and catalyse the creation of a community that cares for one another, especially the vulnerable. In that community, 'socio-economic justice' should be a reality for all (Linthicum 2003:38).

This model helps InnerCHANGE staff see themselves as followers of Christ. In their followership, they prioritise discipleship and the raising of local leaders as seen in Mark 1:16-20. This model also challenges InnerCHANGE staff to strive to be agents of hope in the contexts they serve in. These agents help a community to imagine the society they would like to become and participate in its development. They help to catalyse the rediscovery of a sense of hope in places it has been lost. In many of the contexts they serve in, there seems to be systemic and collective trauma that leads people to uncritically accept that they are inferior to others and they cannot be part of the solution to issues that affect them.

Like Jesus came to dwell amongst us, InnerCHANGE seeks to dwell amongst the people of the context it serves in a meaningful way. It has developed a theology of place as a missional order in its ecclesiology. It believes that 'a comprehensive missional approach to ecclesiology needs to embrace a place and [be] grounded in a neighbourhood' (Niemandt 2019:1). This is why it believes in serving many local communities, one neighbourhood at a time. Fitch (2016:401) posits that 'incarnation comes together in one concrete place'. The incarnation in a particular context prepared Jesus for an active and meaningful mission. InnerCHANGE staff long to be agents of meaningful mission through their commitment to immerse in particular contexts. It is this longing that informs InnerCHANGE method.

A way ICSA tries to emulate the model of Christ is by intentionally walking in the neighbourhoods it serves in to observe, learn and reflect on the best way to serve. In the bible, there are many instances where Jesus walks such as in Luke 24:13. The team does weekly prayer walks, which is not only a discipline to contend for its local community through prayer, it is also a discipline of going out to see and observe what is happening around us. We then bring to the lord what we have experienced through this spiritual exercise because for us, 'prayer is foundational' to any of our ministry activities (Fuder 2014:15). It helps us discern what to do, inspired by what came to our attention during our walk.

We also walk regularly to street corners to talk to neighbours. We are also intentional about attending community events such as ward meetings, funerals and other functions. These events are opportunities for us to learn from our local community about what meaningful mission could look like. We also drive regularly around our local community as an exercise to continue observing and learning. For our weekly activities, we spend more time outdoors in the community than indoors around our office desks. It is from these interactions of our local community that we started different ministry initiatives. Because of the latter, we do monthly home visits to the families of our beneficiaries. This routine is a way to continue to learn about a meaningful mission that our neighbours can identify with. This routine also helps us to try and reflect the agenda of our local community into our ministry praxis. Stevens (2017:204) describes this approach as 'grounded theology' because it is developed from lived experiences of grassroots people. As a mission organisation, we believe that 'the gospel is good news when it provides answers for a particular people living in a particular place at a particular time' (Koning \& Buys 2016:2). Listening to our neighbours is a critical element in our desire to incarnationally contextualise InnerCHANGE ministry approach. It has led us into the current ministry initiatives we are involved in. It has also challenged us to learn to be honest about our capacity and ability. Our neighbours have suggested things such as opening a soup kitchen, regularly distributing food parcels or sponsoring adult football teams that we could not do. Efforts to continue listening in order to identity with the residents of its context is one of ICSA's best understandings of incarnational ministry. It sees incarnation as 'the ultimate example of ... the translatability of the gospel' into an understandable language (Niemandt 2017:4). This is an effort seeking to communicate a meaningful gospel to everyone starting from local contexts. This effort motivates the method we use.

\section{The method}

InnerCHANGE uses an action-reflection approach through which it reaches out to people in very practical ways and regularly reflects on actions taken in order to generate 
wisdom for future action. The preference for this approach is motivated by the fact that we live in an age in which many people do not always mean what they say. Most of what is said raises hope that seldom comes to pass. This is why Hayes (2006:113) stresses that the world needs more people to live the good news incarnationally, in a way that can be seen, heard and handled'. InnerCHANGE sees this statement as a principle and attempts to implement it in investing in practical ministry initiatives. This investment is a way to build relationships and disciple neighbours whilst being tangible messengers of love. InnerCHANGE sees practical love as a way to emulate Jesus' legacy. Such love helps ordinary people to equate the biblical message to 'the love of God made visible, able to be touched and felt through physical agents of his kingdom' (Perkins 1993:44). This equation is sometimes made from experiences people have of the 'little bit of good' InnerCHANGE teams do in their contexts (Tutu 2011:9). Staff members are involved in different advocacy causes and practical ministries to the homeless, palliative care patients, to sex workers, to refugees, to the physically disabled, to the drug addicts, in education, in sports, art and to unify the body of Christ in recognising the diversity of its expression. Through this involvement, InnerCHANGE tries to communicate a message through deeds and words.

InnerCHANGE South Africa has extended the InnerCHANGE action-reflection approach to include the generation of theory as a third element. Action or serving in practical ways is the first step of this approach. For example, ICSA has partnered with several businesses to provide 'employment' for many of its neighbours (Kabongo 2020b:1). To date, 139 neighbours have been permanently employed, which has positively contributed to the improvement of the living conditions of the employed and their families. Every week, ICSA runs sports ministry (football, basketball, netball and volleyball), tutoring clubs, a drama club, a beadwork club, teenager mentoring groups and a kids' club. Staff and volunteers run these initiatives. It is in the latter that we disciple our neighbours and try to foster a spirit of 'mutual solidarity' with them (Kabongo 2020a:5). As a team of staff and volunteers, we aim to form 'communities of practice' where we strive to be known by the way we tangibly care for others and connect our action to our followership of Christ (Stevens 2017:203). Our communities of practice aim to foster mutual empowerment so that we can become proactive participants in answering our communal prayers. We understand a community of practice as a team whose priority is to serve neighbours in practical ways. It is from these communities of practice that ICSA recruits its staff.

After running a ministry initiative, a community of practice spends some time debriefing its experience. It takes note of things that stood out and could be a knowledge capital for future actions. InnerCHANGE South Africa is now learning to reflect deeper on what comes out of debriefing times in order to generate a 'theory' that would sharpen its actions and allow it to disseminate its learned concepts in different contexts or settings (Stevens 2017:202). Valuing theory came as an outcome of the author's life reality and experience. $\mathrm{He}$ and his wife founded ICSA in 2008 and relocated to Soshanguve where they still live. They had two young children then. From the first day their family moved to their current context, many children from the neighbourhood being curious about the newcomers, spent the day around their yard. Soon after that, ICSA started its first ministry, which was a kids' club. Since then, the majority of ICSA ministry initiatives revolve around children and teenagers. These age groups seem to be very comfortable at theorising through statements they make and questions they pose. From the author's experience and observation, many of them easily challenge our socially accepted 'practices or routines' and our conventional social wisdom (Hooks 1994:59). They are also open to doing things differently, are adaptable to new ways and have an active imagination of how things could be. Spending time with these age groups has challenged ICSA to constantly think about ways to build a ministry that is relevant and meaningful. InnerCHANGE South Africa has 'found a place of sanctuary in theorising' as an exercise of imagining possibilities of being meaningfully incarnational in its context (Hooks 1994:61). Such an exercise has led it to diversify its ministry initiatives because it values the discipline of imagining new futures and possibilities. This value in theorising has positioned it to start incarnational ministries in various contexts and advise like-minded organisations.

In order to smoothly run all its activities, ICSA registered with the government department of social development as a non-profit organisation. This has allowed it to legally be able to serve all the age groups it has capacity for. This method it uses seeks to communicate a message.

\section{The message}

The main message of incarnational ministry is drawn from John 3:16 where the bible declares that the coming of Jesus to dwell amongst us shows God's love for his creation. InnerCHANGE's choice to serve only in communities of poverty, intends to communicate that love is costly, yet those who are the object of such love are worth it although the world put them at the bottom of social considerations. InnerCHANGE learns this from the bible, which shows a preferential leaning towards the poor (Pr 22:9; Lk 4:18; Mt 25:31-46).

Similar to the community of apostles Jesus gathered before the beginning of his active ministry, InnerCHANGE believes that the most effective way to serve is to do it as a team. Hayes (2006:14) says that 'we believe that one response needed today is to create unique orders-mission communities that are part team, part tribe, part family'. This format strengthens InnerCHANGE staff support system and their accountability to one another in pursuing their common purpose. It also challenges them to synergise their 'relationship with God, other people and the world' (Wright 2010:49). This synergy shapes people into good news agents. The latter are Christians who seek (Kabongo 2020a): 
$[T]$ he peace and prosperity of their context in tangible ways and invites other people to do the same so that quality of life can be improved, lives can flourish and communities can be built from the inside out. (p. 6).

Good news agents believe in multiplication. Hence, InnerCHANGE believes in the prioritisation of nurturing local leaders whose actions are a tangible sign of the mercy of Christ, whose intimate relationship with Christ is positively transformative and whose voice and action seek to establish a just society.

InnerCHANGE South Africa also tries to convey the message that God so loved the world that he would like our living conditions to be improved. It stresses that such an improvement will only be possible and sustainable if it is a collective effort of people of a particular context. Such efforts are acts of 'solidarity' with one another (Hirsch 2006:132). An intentional investment into acts of solidarity in our local communities would pave the way for the democratisation of mission. This means that ordinary community members will be empowered to become good news agents in their neighbourhoods of residence. A way to be such is to be engaged 'in a variety of sectors of society' and make a positive impact in them (Frost \& Rice 2017:33). This is why all ICSA practical ministries are run by local leaders because it believes that neighbours should contribute to the shaping of an incarnational ministry such as InnerCHANGE. Such efforts teach neighbours to be community developers and solution seekers. It also provides a pathway for ICSA to continue to incarnate in its context so that its discipleship model can be tangible good news because it would be empowering to ordinary people and transformative in life-giving ways. The involvement of neighbours has provided the human capacity ICSA needs to provide quality service in its various initiatives. It has also provided to the local community people who care for their communal welfare. InnerCHANGE South Africa ability to attract and equip neighbours as good news agents is still work in progress. One of the challenges on this journey is to help neighbours see the big picture of community development as a collective effort. Some neighbours see their involvement with ICSA as primarily an opportunity to earn an income, not to serve others. Others are uncomfortable with its focus on discipleship in all its initiatives because it feels discriminatory to people of other faiths. InnerCHANGE South Africa is learning to remain present to this challenge and be considerate of any criticism levelled against its approach. In this process, it is learning to creatively communicate its big picture, which is the catalysing of agency from below in building grassroots communities. InnerCHANGE South Africa is constantly encouraged in this effort of communication by Antoine de Saint-Exupery (1950):

If you want to build a ship, don't drum up people to collect wood and don't assign them tasks and work, but rather teach them to long for the endless immensity of the sea. (p. 251)

The endless immensity of the sea is for ordinary people to understand that as a community and society, we are better together in our efforts to improve the quality of our lives than alone or just a small group. The practising of spiritual disciplines helps to stay in tune with this message.

\section{Spiritual discipline}

InnerCHANGE invests many time practising different spiritual disciplines because they help 'wean us away from self-reliance to God-reliance' (Hayes 2006:120). Our post-modern era seems to be very obsessed with control and independence. Reliance on God cultivates the virtues of humility, listening, patience and submission, which are needed in working in communities of poverty. It also sustains InnerCHANGE staff in their contexts of service that are generally traumatic. Many communities of poverty are characterised by high levels of violence, drug and alcohol abuse, the neglect of vulnerable people such as women and children. InnerCHANGE staffs have had to speak into these issues. The psychiatrist Cloninger (2004) was once asked the question of how people can remain 'healthy, happy and fulfilled' despite traumatic circumstances around them. He answered that the spiritual development of greater reliance on God was key to the survival of people living in such circumstances. Reliance on God makes the dealing with traumatic situations bearable whilst sustaining InnerCHANGE staff.

Similar to all InnerCHANGE staff, ICSA staffs practice different spiritual disciplines as a way to remain connected to God. They see their mission in the context they live in as a response to God's calling in their lives. A spiritual discipline they have learned to practice regularly is that of silence. They do their prayer walk in silence and spend intentional moments of silence during other prayer times and before the debrief times after ministry activities. Silence also helps them to listen and observe more as a learning exercise. Silence is an important discipline in the township context where they serve. Townships are known for loud noises from the tavern music, hooting public transporters, conversations amongst people, screaming children and car speedsters. It is normal for another person to add to the existing noise. The team is been learning not to add to this existing noise, which can create a cacophony, but prayerfully be present to those noises and learn to be good news agents as a result.

It also practices fasting regularly. It has learned to not limit this discipline to food, but to other things that sometimes negatively shift our priorities such as the internet, television, cellphone, computer and so on. The above-mentioned disciplines and many others we practice have become habits that teach us to rely on God in everything.

Something that requires many reliance on God is financial and material provision. InnerCHANGE staffs from all over the world raise financial support from individuals, foundations, churches and businesses for salaries and ministry expenses. Some of our organisation leaders from the west equate someone's confirmation of calling to mission to their ability to raise $100 \%$ of their personal financial support. The reality of ICSA is that none of its staff is fully funded with this model of personal support raising. It is been exploring different avenues to financially and materially become a sustainable ministry. One of the avenues it has explored and still working on, is 
group support raising. It believes that 'support-raising is about God's children working together, each dependent on the other, to see God's plan fulfilled in their lives ...' (Wilson 2011:5). It has also explored having some people work part-time. Others have worked full-time on weekdays and serve their local communities on weekends. For its recruits from its local context, ICSA has a three-level process of its funding approach: raising funds for, with and by. In the beginning, the salary of the new staff is raised for them. Then, they partner with their teammates to raise funds as a team using the existing network of the team. Finally, they are expected to raise funds by taking initiatives in building new connections to be added to the team network. This process is still an experiment. It is still a learning curve and ICSA would like to remain a faithful student of its experiments. It is still like a 'pregnancy' - a labour intensive process with the expectation of a new and fulfilling life (Frost \& Rice 2017:1). The goal is to seek sustainability whilst remaining focused on our calling to disciple and raise local leaders.

\section{Conclusion}

This article was a case study reflecting on how ICSA has been contextualising InnerCHANGE incarnational ministry framework of a model of Christ, method, message and spiritual discipline. Incarnational ministry is generally seen as intentionality to identify with the vulnerable in society. InnerCHANGE South Africa has been making efforts to identify with its neighbours so that the biblical message could be seen as relevant good news that leads to better wellbeing of individuals and communities. These efforts are also made in order to overcome the danger of implementing the missional order principles and practices that may not necessarily be relevant in the context ICSA serves in. These efforts are work in progress with encouraging signs and challenges along the way.

\section{Acknowledgements Competing interests}

The author declares that they have no financial or personal relationships that may have inappropriately influenced them in writing this article.

\section{Author's contributions}

K.T.L.K. is the sole author of this article.

\section{Ethical considerations}

This article followed all ethical standards for research without direct contact with human or animal subjects.

\section{Funding information}

This research received no specific grant from any funding agency in the public, commercial or not-for-profit sectors.

\section{Data availability}

Data sharing is not applicable to this article as no new data were created or analysed in this study.

\section{Disclaimer}

The views and opinions expressed in this article are those of the authors and do not necessarily reflect the official policy or position of any affiliated agency of the authors.

\section{References}

Bangura, J.B., 2016, 'The gospel in context: Hiebert's critical contextualisation and charismatic movements in Sierra Leone', In Die Skriflig 50(1), a2061. https://doi. org/10.4102/ids.v50i1.2061

Bevans, S. \& Schroeder, R., 2004, Constants in context: A theology of mission for today, Orbis, Maryknoll, New York, NY.

Beyers, J., 2016, 'Theology and higher education: The place of a faculty of theology at a South Africa university', HTS Teologiese Studies/Theological Studies 72(4), a3450. https://doi.org/10.4102/hts.v72i4.3450

Cloninger, C.R., 2004, Feeling good: The science of well-being, Oxford University Press, New York, NY.

De Saint-Exupery, A., 1950, The wisdom of the Sands, Harcourt Brace, New York, NY. Fitch, D.E., 2016, Faithful presence: Seven disciplines that shape the church for mission, Kindle edn., InterVarsity Press, Downers Grove, IL.

Frost, M. \& Rice, C., 2017, To alter your world: Partnering with God to rebirth our communities, InterVarsity Press, Downers Grove, IL.

Fuder, J., 2014, Neighborhood mapping: How to make your church invaluable to the community, Moody Publishers, Chicago, IL.

Hayes, J.B., 2006, Sub-merge: Living deep in a shallow world: Service, justice and contemplation among the world's poor, Regal: From Gospel Light Ventura, Pasadena, CA

Hirsch, A., 2006, The forgotten ways: Reactivating the missional church, Brazos, Grand Rapids, MI.

Hooks, B., 1994, Teaching to transgress: Education as the practice of freedom, Routledge, New York, NY

Innerchange.org., 2020, About, viewed 24 September 2020, from https://www. innerchange.org.

Kabongo, K.T.L., 2020a, 'Migration to South Africa: A missional reflection of a refugee using Jeremiah $29: 4-12$ as an interpretive framework', Theologia Viatorum 44(1), a57. https://doi.org/10.4102/tv.v44i1.57

Kabongo, K.T.L., 2020b, 'A partnership for prosperity agency: A case study of InnerCHANGE South Africa', Theologia Viatorum 44(1), a48. https://doi. org/10.4102/tv.v44i1.48

Koning, J. \& Buys, P.J., 2016, 'South African Reformed Baptists and contextualisation: Contemporary understanding, attitudes and praxis', In Die Skriflig 50(4), a2018. https://doi.org/10.4102/ids.v50i4.2018

Linthicum, R.C., 2003, Transformation power: Biblical strategies for making a difference in your community, Intervarsity Press, Downers Grove, IL.

Niemandt, C.J.P., 2017, 'Mission as breaking down walls, opening gates and empowering traders: From contextualisation to deep contextualisation', HTS Teologiese Studies/Theological Studies 73(1), 4621. https://doi.org/10.4102/ hts.v73i1.4621

Niemandt, C.J.P., 2019, 'Rooted in Christ, grounded in neighbourhoods - A theology of place', Verbum et Ecclesia 40(1), a1997. https://doi.org/10.4102/ve. v40i1.1997

Perkins, J.M., 1993, Beyond charity: The call to Christian community development, Baker Books, Grand Rapids, MI.

Stevens, B.A., 2017, 'Grounded theology? A call for a community of practice', Practical Theology 10(2), 201-206. https://doi.org/10.1080/1756073X.2017. 1308455

Tutu, D., 2011, God has a dream: A vision of hope for our times, Random House, Manhattan.

Wilson, M., 2011, Funding the family business: A handbook for raising personal support, rev. edn., Stewardship, Dundee.

Wright, C.J.H., 2010, The mission of God's people: A biblical theology of the church's mission (Biblical theology of life), Zondervan, Grand Rapids, MI. 